\title{
KOHESIVITAS TIM DAN EFIKASI DIRI SEBAGAI PREDIKTOR PRESTASI OLAHRAGA TIM
}

\author{
Dimyati \\ Universilas Negeri Yogyakarta
}

\begin{abstract}
This research aimed to examine the relationship between team cohesiveness and self efficacy logetherly with the achievement of the water polo team, whereas the specifics goals to be sought ane : (1) the relationship between cohesiveness and the achievement of the water polo team, (2) the relationship between self efficacy and the team achievement, (3) the differences between cohesiveness degree and self efficasy of each water polo team.

The subject of the research were water polo athletes taking part in National Games (PON) XV in the year of 2000 in Surabaya comprising 65 people. The method and the instrument used are questionnaire method modified Likert scale. The leam cohesion questionnair.e (TCQ) instrument is used to find out the team cohesiveness. Additionally. self efficacy scale contructed from the Bandura theory is employed to figure out self efficaccy.

The computation using regression analysis in the value of $A=0,951$ $(p<0,05)$. If implies that the there exist a positif and significant relationship between team cohesiveness as well as self efficacy along with achievement of water poto team. Product moment analysis is carried out of seek the relationship between team cohesiveness and the team achievement resulting in the value of $r=0,973$, whereas the relationship between self efficacy and the achievement of water polo team meet the value of $r=0,975$. Based on the one-way vatian analysis, the significant difference $(F=19,117)$ of the team cohesiveness as will as self efficacy $(F=26,542)$ of each water pob team is revealed.
\end{abstract}

Keywords: cohesiveness tearn - self efficacy - achievement - water polo.

Dimyati, adalah dosen Psikologi Olahraga Fakultas llmu Keolahragaan Universitas Negeri Yogyakarta. Memperoleh gelar. sarjana (S-1) tahun 1991 pada Fakultas Olahraga dan Kesehatan Universitas Pendidikan Indonesia (dulu IKIP Bandung). Gelar MSi, pada bidang Psikologi Sosial diperoleh pada tahun 2000 dari UGM. Dewasa in sedang mendalami kajian aktivitas fisik dengan fungsi kognilit, dain dimensidimensi psikologis dalam pembelajaran pendidikan jasmani.

\section{PENDAHULUAN}

$\mathbf{P}$ restasi olahraga merupakan fenomena global yang selalu menarik untuk dikaji. baik dari segi proses terjadinya maupun bentuk keindahan gerak yang diwujudkannya. Hampir seluruh bangsa d dunia tidak lepas dari uscha untuk menciptakan prestasi dalam kegiatan olahraganya, sebab dengan prestasi olahraga yang tinggi suatu bangsa akan mendapat tempat terhormat di antara bangsa-bangsa lain di dunia. Keberhasilan Indonesia yang untuk pertàma kalinya ikut 
South East Asean Games (SEA Games) tahun 1977 df Kuala Lumpur dan langsung jadi juara umum telah menumbuhkan kebanggaan dan harga diri bangsa dan untuk sekian waktu prestasi itu hang at dibicarakan oieh para pengamat di dalam maupun d luar negeri (Siregar, 1978). Dalam konteks itu pula pemerintah menaruh perhatian yang besar atas perkembangan prestasi olahraga nasional. Sebagaimana yang dituangkan dalam Sasaran Rencana Pembangunan Lima Tahun ke-enam (Repelita VI) GBHN 1993-1998, yaitu meningkatkan peringkat pada Asian Games dan dipertahankannya juara umum pada SEA Games, meningkatkan perolehan medali emas pada Olympiade. Namun dalam realitas perkembangan selanjutnya ternyata Indonesia kalah bersaing dan tertinggal baik dalam tingkatan regional maupun internasional. Prestasi kontingen Indonesia yang terpuruk di posisi ke tiga di bawah Thailand dan Malayasia pada SEA Games XX tahun 1999 d Brunei Darussalam merupakan prestasi terburuk dalam sejarah keikutsertaan Indonesia pada pesta olahraga negara-negara Asla Tenggara tersebut.

Nossek (1982) mengatakan bahwa usaha pembinaan olahraga untuk menciptakan prestasi yang tinggi, merupakan masalah kompleks dan banyak tergantung serta dipengaruhi oleh berbagai faktor. Menurut Setyobroto (1993), prestasi Korea Selatan menjadi juara IV pada Olympiade 1988, begitu pula kemajuan RRC pada beberapa cabang olahraga sepertil renang, atletik dan angkat besi yang mulai menunjukkan kelas dunia, itu berkat dukungan ilmuwan dan peneliti. Pate dkk. (1993) mengatakan bahwa sampai saat ini ada tiga ilmu dasaryang telah berkembang menjadi subdisiplin ilmu yang mendukung praktek kepelatihan olahragawan yang sempurna, yaltu bidang Psikologi Olahraga, Biomekanika dan Psikologi Latihan.
Singgih (1989; 2000) mengatakan bahwa d luar negeri Psikologi Olahraga sudah sedemikian maju, sedang di Indonesia masih belum banyak digumuli. Sementara itu kebutuhan akan ahli Psikologi dalam perkembangan olahraga, saat ini sangat mendesak. Bisajadi ketertinggalan indonesia dari negara-negara lain dalam arena olahraga baik di tingkat regional maupun internasional, salah satunya disebabkan oleh kurang diperhatikannya kajian dan penerapan Psikologi dalam bidang olahraga. Davies (1989) mengatakan bahwa Psikologi adalah ilmu yang mempelajari perilaku manısia; sedangkan Psiklogi Olahraga merupakan sub disiplin Psikologi yang menerapkan prinsip-prinsip psikologi dalam olahraga dan usaha-usaha untuk menggambarkan, menjelaskan dan mempredlksi prestasi dalam olahraga. Menurut Williams (1993) aspek-aspek yang menjadi kajian psikologi olahraga d antaranya motivasi, kepribadian, agresivitas dan kekerasan, kepemimpinan, dinamika kelompok dan berbagai dimensi lain yang terkait dalam perilaku atlet dalam olahraga.

G.l (1986) mengatakan bahna dinamika kelompok dalam clahraga sangat menentukan keberhasilan atau kegagalan suatu tim. Menurut Bird dan Cripe (1986) setiap saat para pemain harus berinteraksi untuk mencapal hasil yang positif dan behagai dinamika serta proses interpersonal antara anggota tim harus betul-betul dipertimbangkan d samping tentunya rasa optimisme individu untuk berprestasi. Shaw (1979) menyebut hal tersebut dengan istilah kohesi, yaitu interaksi di antara anggota tim, bagaimana anggota tim itu saling menyukai, saling mencintai satu dengan yang lairinya. Carron (1993) mendefinisikan kohesivitas sebagal proses dinamis yang merefleksikan kecendiungan anggota tim secara bersamasama untuk tetap bertahan dalam bekerjasama mencapal tujuan. Kohesivitas tim 
dalam konteks olahraga adalah derajat dari para pemain untuk tetap bertahan dalam tim dan secara bersama-sama tetap bersatu untuk bekerjasama mencapai tujuan tim yaitu kemenangan.

Cox (1990) mengatakan berdasarkan berbagai hasil kajlan diketahui bahwa kohesivitas tim setidak-tidaknya terdiri darl dua dimensi yang berdiri sendirl. Pertama dimensi yang berhubungan dengan interpersonal attraction (daya tarik antar anggota) yang didefinisikan sebagal social cohesion, yaitu derajat interaksi anggota tim untuk saling menyukal satu sama lainnya dakam tim. Dimensi kedua adalah task cohesion, yaitu yang menggambarkan derajat dari anggota tim untuk bekerJasama dalam mencapai sasaran atau tugas tertentu.

Straub (1980) mengatakan bahwa para pelatih olahraga menyadari kohesivitas merupakan dimensi yang penting dari keberhasilan tim. Anshel (1990) menegaskan bahwa selama bertahun-tahun para pelatih berasumsi perasaan positif diantara anggota tim menghasilkan prestasi yang lebih balk dalam tim olahraga. Keyakinan dan asumsi para pelatih ini berhasil dibuktikan Nixon (dalam Loy dkk., 1978) dalam teorinya yang disebut "An Axiomatic Theory"yang saiah satu dalinya menyebutkan bahwa tingkat kohesivitas tim yang tinggi mengindikasikan hubungan langsung yang positif dengan prestasi tim. Carron (dajam Williams, 1993) mengatakan bahwa kohesi adalah norma untuk prestasi dan sangat mempengaruhi pencapaian produktivitas keiompok. Secara umum kohesivitas tim merupakan hai yang paling penting agar tim berhasil, terutama dalam olahraga yang sangat tergantung pada interaksi anggota tim selama permainan berlangsung (Pate, dkk., 1993). Hasil peneiltian yang dilakukan oieh Martens dan Petersen (dalam Straub, 1980) terhadap 1200 pemain bola basket putra dari 144 tim sekolah yang bertanding di universitas fllinois menunjukkan bahwa kohesivitas tim berhubungan positif dengan prestasi tim. Menurut Stogdiii (dalam Williams, 1993) berbagai penelitian pada limu Manajemen, Psikologi dan Olahraga menunjukkan bahwa hasil analis is terhadap 34 hasil peneiitian membuktikan 12 berkorelasi positif terhadap prestasi, 11 berkorelasi negatif dan 12 tidak menunjukkan berhubungan dengan prestasi. Oleh karena itu harapan bahwa kohesi dapat meningkatkan prestasi terus mengundang perdebatan, jadi tidak semata-mata diterima sebagai ada hubungan positif atau negatif (Gully dkk., 1995). Kajian mengenai kohesivitas tim ini menjadi lebih relevan dan penting terutama dikaitkan dengan kegagalan totai kontingen indonesla di SEA Games XX tahun 1999 di Brunei Darussaiam yang terjadi pada cabang-cabang olahraga tim yang tergolong interactive sport yaitu cabang-cabang olahraga yang membutuhkan interaksi, ker jasama dan koordinasi di antara para pemain seperti cabang olahraga sepak bola, bolabasket, sepaktakraw, hoki dan polo air. Cabang-cabang olahraga tersebut tidak satu pun yang menghasilkan medali emas bagi kontingen Indonesia.

Dl sisi lain Langfred (1989) mengatakan bahwa hasli penelitian dalam bidang manajemen menunjukkan implikasi praktis pada prestasi kerja tim dipengaruhi oleh kombinasi kohesivitas dan norma-norma tim jad tidak hanya kohesivitas tim semata. Menurut Gill (1986), kepercayaan diri pemain merupakanfaktoryang menentukan dalam olahraga, Morris dan Summers (1995) mengatakan bahwa tidak sedikit dalam olahraga dan latihan keyakinan masingmasing individu pemain merupakan elemen penting untuk mencapai prestasi secara keseiuruhan. Lebih lanjut dikatakan bahwa satu konsep keyakinan diri yang berhasil dibuktikan dalam bidang oiahraga yaitu eflkasi diri. Bandura (1986) mendefinisikan 
efikasi diri mengacu pada suatu keyakinan seseorang atas kemampuannya untuk melaksanakan tugas khusus atau bagian darl berbagal komponen tugas. Lebih jauh dikatakan bahwa efkasi diri tidak berkaitan dengan kemampuan yang sebenarnya melainkan terkait dengan keyakinan seseorang.

Etikasi diri seseorang menurut Bandura (1977a) dibedakan atas dasar beberapa dimensl yang memiliki implikasi pentlng terhadapprestasi. Dimensi tersebut: Pertama, tingkat kesulitas tugas (magnitude), yaltu yang berhubungan dengan tingkat kesulitan suatu tugas. Indivldu akan mencoba perilaku yang dla merasa mampu melakukannya dan akan menghindari situasi dan perilaku yang of luar batas kemampuan yang dirasakan; Kiedua, luas bidang perllaku (generality), merupakan dimensi yang berhubungan dengan luas bidang perilaku. Beberapa pengharapan terbatas pada bidang tingkah laku yang khusus dan beberapa pengaharapan mungkin menyebar meliputi berbagal bldang tingkah laku. Ketlga, kemantapan keyaklnan (strength), adalah derajat kemampuan Individu terhadap keyakinan atau pengharapannya. Pengharapan yang lemah akan mudah dlgoyahkan oleh pengalaman-pengaiaman yang tidak menunjang. Pengharapan yang mantap sebaliknya akan mendorong Individu untuk tetap bertahan dalam usahanya walaupun mungkin ditemukan yang tidak menunjang.

Locke dkk. (1984) mengatakan bahwa efikasi diri yang tinggi akan menumbuhkan rasa percaya diri akan kemampuan dirinya dalam melaksanakan tugas. Feitz (1982) mengatakan bahwa efikasi diri menjadi suatu variabel kuncl dalam pencapalan prestasl olahraga dan kesehatan serta tingkah laku lathan pada umumnya. Bentuk eflkasi diri yang tepat dapat mempertinggl balk fits prestasi yang berupa aktivitas fisik maupun prestasi akademik (Baron dan Byme, 1997). Berdasarpada teori belajar sosial milik Bandura
Feltz (1982) telah mengujt hubungan antara efikasi diri, dengan pencapaian prestasi dan gejolak fisiologis pada mahasiswa dengan menggunakan model yang bersifat kausal, hasil penelitian itu menunjukkan bahwa efikasi diri merupakan prediktor yang paling kuat bag prestasi penyelam. Morris dan Summers (1995) meiaporkan bahwa sejumlah penelitian telah mempertimbangkan hubungan antara efikasi dri dan prestas olahraga kompetitif. Weiss dkk., (1989) mengukur efikasi diri dan prestasi pesenampesenam muda (putri) yang bertanding dalam suatu kejuaraan dengan tingkat kompetisi yang relatif tinggl menunjukkan bahwa ada hubungan yang signifikan ( $r=$ $0,57)$ antara efikasi diri dan prestasi pesenam tersebut. Uraian tersebut menegaskan bahwa efikasi dirl merupakan faktor penting yang mempengaruhi prestasi, maka implikasi praktls di bidang olahraga khususnya cabang olahraga tim yang bersifat interaktil merupakan bahan kajlan yang menarik untuk diteliti lebih lanjut. Pertanyaan yang kemudian muncul, apakah ada hubungan yang posittf antara tingkat eflkasi dirl para pernain dengan prestasl tim olahraga yang berslfat Interaktif seperti cabang polo air?

Cabang polo air dijadikan objek dalam penelitian inl didasarkan pada dua pertimbangan, yaitu (1) teoritis dan (2) empiris. Pertimbangan teoritis menunjukkan bahwa cabang olahraga polo air hingga saat inl dalam berbagai literatur menunjukkan cabang polo air belum pernah diteliti, sedangkan pertimbangan empiris menunjukkan bahwa cabang polo air di Indonesia balk dari segi perkembangan maupun prestasi yang diraih sangat tertinggal dlbandlngkan dengan cabang olahraga yang lain.

Werner (1996) mendefinislkan bahwa polo air merupakan cabang olahraga yang dapat dimainkan oleh putra maupun putri yang terdiri dari 7 orang dapat langsung turun dalam permainan, sedang 6 orang 
pemain lainnya sebagal cadangan. Tim yang paling banyak memasukkan bola ke gawang iawan, maka tim tersebut dinyatakan sebagai pemenang. Polo airtermasuk cabang olahraga yang tergolong ke dalam interactive sport (Cox, 1990) yaitu cabang olahraga yang membutuhkan interaksi dan kerjasama di antara pernain. Sebagal cabang olahraga tim, interaksi dan kerjasama antar pemain dalam tim merupakan prasyarat untuk mencapai prestasi.

Yulk (1998) mengatakan bahwa kecendrungan perkembangan organisasi dewasa ini leblh menekankan pada pentingnya tanggung jawab tim dari pada tanggung jawab yang bersifat individual. Menurut Cratty (1981) banyak penelitian dalam bidang Psikologi Industri mengungkapkan bahwa ada hubungan yang saling menunjang antara interaksi soslal dan afiliasi sebelumnya dengan produktivitas tim. Gill (1986) mengatakan bahwa olahraga pada hakekatnya merupakan aktivitas yang dllakukan dalam tim. Oleh karena itu pemahaman terhadap konsep dan bagaimana upaya untuk mewujudkan prestasi tim merupakan isu penting dalam oiahraga. Steiner (dalam Shaw, 1979) mengatakan bahwa prestasl tim sangat tergantung pada tiga variabel, yaitu (1) apa yang dituntut oleh tugas (task demand); (2) sumber daya tim (resources), dan (3) proses (process).

Task demand mencakup persyaratan yang dituntut oleh tim, misalnya task de mand dalam rencana membangun rumah pertu mendeskripsikan tertang struktur, bahan, alat, dan langkah-langkah yang diambil untuk konstruksi itu. Task demands menentukan resources apa yang dibutuhkan. Resources merupakan segala kemampuan atau sumber yang terkait dengan keterampilan, alat-alat dan sebagainya yang dimiliki tim yang akan melaksanakan tugas. Distribusi resources ini besar sekali sumbangannya terhadap prestasi tim. Pro- cess merupakan langkah-langkah yang diambil oleh tim dalam menjalankan tugas. Proses ini juga tidak hanya mencakup berbagai tindakan (actions) yang langsung dan relevan dengan tugas, tetapi juga meliputi interpersonal dan intrapersonal actions anggota tim dalam wujud yang produktif maupun yang tidak produktif.

Lebih lanjut Steiner (daiam Morris \& Summers, 1995 dan Gill, 1986) telah mengembangkan teori tersebut yang diterapkan dalam konteks prestasl olahraga yang diformulasikan sebagaimana tertera di bawahini:

Actual productlvity = Potential productivlty - Louses due to foulty procese

Actual productivity merupakan refleksi dari hasil akhir yang dicapai tim olahraga, yaitu menupakan perbandirgan antara menang dan kalah. Potential productivit ymerupakan potensi yang dimiliki tim untuk berprestasi berdasarkan pada sumber-sumber yang sesual dengan tugas dan kebutuhan yang diperlukan tim. Kemampuan keterampiian indlviduai yang ditampilkan individu bisa jad merupakan sumber yang penting untuk olahraga tim. Seperti posturtubuh yang tingg. kekuatan otot kaki yang eksploslf merupakan sumber-sumber yang sesual dengan karakteritik permainan bola voli, tetapi tidak relevan untuk cabang olahraga bowling. Kesesuaian persyaratan yang dituntut oleh tugas berdasarkan pada sumber-sumber yang relevan dengan kebutuhan tim akan menentukan prestasl tim. Namun Steiner menje laskan bahwa prestasi aktual tim berdasar pada potential productivity akan hilang karena foulty process. Foulty process adalah tidak efektifnya penggunaan sumbersumber yang dimiliki untuk melaksanakan tugas yang dibutuhkan yang menyebabkan kehilangan dua hal, yaitu kehilangan koordinasl dan kehilangan motivasi. 
Uraian di atas menegaskan bahwa keterampilan dan kemampuan individual para pemain merupakan kualifikasi yang penting dan terkait dengan olahraga, juga merupakan komponen utama potensi prestasi tim. Namun demikian pada cabang olahraga yang tergolong interaktif seperti polo air yang membutuhkan interaksi dan koordinasi diantara sesama anggota tim, apabila proses interaksi dan koordinasi tersebut tidak berjalan efektif maka potensi yang dimiliki tim menjadi hilang. Kegagalan dalam proses ini akan mengakibatkan hilangnya koordinasi dan motivasi tim. Menurut Srobe dan Frey (1982) hilangnya motivasi dan koordinasi tim merupakan penyebab hilangny a prestasi tim. Jhonson \&. Jhonson (1991) menegaskan bahwa prestasi tim tidak tergantung pada fungsi dan kompetensi teknis serta kemampuan kerja anggota tim $_{\mathrm{r}}$ tapi yang utama tergantung pada komponen: (1) penekanan pada sasaran tirn; (2) pembertukan dan pemblasaan pola kerja tim; dan (3) pengembangan perasaan identitas tim. Prestasi tim cabang olahraga yang bersifat interaktif seperti polo air adalah merupakan keberhasilan dari kualitas usaha para pemain sebagai anggota tim yang sangat tergantung pada proses interaksi, koordinasi dan kerjasama yang efektif di antara sesama anggota tim.

\section{HIPOTESIS}

Berdasarkan landasan teori tersebut di atas, dapat diajukan hipotesis penelitian sebagai berikut: Ada hubungan antara kohesivitas tim dan efikasi diri secara bersama-sama dengan prestasi tin polo air. Penelitian ini selian ingin membuktikan hipotesis tersebut, juga lebih jauh ingin mengetahui: (1) Ada hubungan positif antara Kohesivitas tim dengan prestasi tim polo air; (2) Ada hubungan positif antara efikasi diri dengan prestasi tim polo air; dan (3) Ada perbedaan tingkat kohesivitas tim dan efikasi diri di antara masing-masing tim.

\section{METODE PENELITIAN}

Variabel-variabel yang terdapat dalam penelitian ini adalah: (i) prestasl tim polo air, sebagai variabel dependen, (ii) Kohesivitas tim, sebagal varlabel independen pertama, dan (iii) Efikasi diri sebagal variabel independen kedua.

Subjek penelitian adalah para pemain polo air peserta PON XV tahun 2000 di Surabaya yang tergabung dalam lima tim, yaitu tim DKI Jakarta, Jawa Barat, Jawa Timur, Jambi dan Sumatra Utara berjumlah 65 orang. Rician subjek tertera pada tabel 1 di bawah ini.

Tabel 1

Subjek Penalitan

\begin{tabular}{|c|l|l|}
\hline No. & Nama Timoaarah & Jumlah Anggota Tim \\
\hline 1 & DKI Jakarta & 13 orang \\
2 & Jawa Barat & 13 orang \\
3 & Jawa Timur & 13 orang \\
4 & Jambi & 13 orang \\
5 & Sumatra Utara & 13 orang \\
\hline & Jumlah & 66 orang \\
\hline
\end{tabular}


Penelitian ini merupakan penelitian survei yang ditujukan untuk menjelasken dan mengkaji hubungan kausal antara dua variabel independen yaitu kohesivitas tim sebagai variabel independen pertama, dan efikasi diti sebagal variabel independen kedua, sedangkanvariabel dependenadalah prestasi tim polo air. Instrumen untuk mengukur kohesivitas tim dan efikasi diri menggunakan angkel dengan model skala Likert yang dimodifikasi.

Untuk mengungkap data mengenai kohesivitas tim digunakan Team Cohesion Questionnaire (TCQ) yang dikembangkan oleh Gruber dan Gray (dalam Cox, 1990). Setelah diadakan try-out dan dianalisis didapatkan hasil bahwa angket kohesivitas tim memiliki koefisien validitas bergerak dari 0,437 sampai dengan 0,796 pada taraf signifikansl $p \& 0,05$ dan koefisien reliabilitasnya sebesar0,972. Untukangket efikasi diri yang merupakan hasil konstruksi dari teori Bandura diperoleh koefisien validitas yang bergerak dari 0,420 sampai dengan 0,939 dengan taraf signifikan $P \varepsilon$ 0,05 , sedang koefisien reliabilitasnya sebesar0,979. Sedangkan data prestasi tim polo ait merupakan data hasil akhir pertandingan lima tim di peroleh dari Panitia Pelaksana cabang renang PON XV, yang dikelompokan ke dalam empat komponen prestasl, yaitu (1) jumlah skor memasukan; (2) jumlah skor kemasukan, (3) jumlah selisih memasukan dengan kemasukan; dan (4) skor nilai masing-masing tim.

Data yang diperoleh dianalisis dengan metode statistik. Teknik statistik yang digunakan adalah regres I dua prediktor Untuk mengujl signifikansi hubungan antara kohesivitas tim dan efikasi diri dengan prestasi tim polo air. Selanjutnya untuk mengetahui hubungan antara kohesivitas tim dengan prestasl tim polo air dan hubungan antara efikasi diri dengan prestasi tim polo air digunakan teknik statistik product moment dari Pearson. Sedangkan untuk menguji perbedaan tingkat kohesivitas tim dan efikasi diti pada masing-masing tim digunakan teknik statistik varian satu jalur.

\section{HASIL PENELITIAN}

Deskripsi dała penelitian yang dijadikan acuan dalam penelitian ini tertera pada tabel 2 di bawah ini.

Tabel 2

Deskripsi Data Fenelitian Variabel Kohesivitas Tim, Efikasl Dirl dan Prestasl Tim Polo alr *

\begin{tabular}{|l|c|c|c|c|c|c|c|c|c|}
\hline \multirow{2}{*}{$\begin{array}{c}\text { Nama } \\
\text { Tim }\end{array}$} & \multicolumn{3}{|c|}{ Skor } & \multicolumn{3}{c|}{ Skor } & \multicolumn{5}{c|}{ Skor } \\
\cline { 2 - 10 } & $X 1$ & Ferata & $X 2$ & Ferata & $Y 1$ & $Y 2$ & $Y 3$ & $Y 4$ & $Y$ \\
\hline DKI & 2125 & 163,462 & 2093 & 161,000 & 43 & -28 & 15 & 8 & 59,500 \\
Jatim & 2051 & 157,769 & 2139 & 164,538 & 53 & -31 & 22 & 6 & 60,000 \\
Sumut & 1913 & 147,154 & 2004 & 154,154 & 37 & -37 & 0 & 4 & 49,750 \\
Jabar & 1833 & 141,000 & 1752 & 134,769 & 30 & -41 & -11 & 2 & 43,500 \\
Jambi & 1551 & $\$ 19,308$ & 1493 & 114,846 & 24 & -46 & -22 & 0 & 37,250 \\
\hline
\end{tabular}

Keterangan:

$X_{1}=$ Kohesivitas tim

$X_{2}=$ Efikasi diri

$Y_{1}=$ Memasukan

$Y_{2}=$ Kemusukan

$Y_{3}=$ Selisith

$Y_{4}=$ Nilai rangking

$Y$ a Rerath prestasi tim polo air. 
Selanjutnya data penelitian di atas dianalisis dengan menggunakan teknik statistik yang sesual dengan tujuan penelitian dan diperoleh hasil sebagaimana tersebut di bawah ini :

1. Koefisien korelasi ganda antara kohesivitas tim dan efikasi diri terhadap prestasi tim polo air (Ry. 1.2) adalah sebesar 0,975; dan $F$ regresi sebesar 19,252 dengan $p<0,05$. Ini berartibahwa terdapat korelasi yang sangat signifikan antara kohesivitas tim dan efikasi diri secara bersama-sama terhadap prestasi tim polo air. Sumbangan efektif kohesivitas tim terhadap prestasi tim polo air adalah 71,319 persen, sedangkan sumbangan efektif efikasi diri terhadap prestasi tim polo air sebesar 23,743 persen. Secara bersama-sama koefisien variabel kohesivitas tim dan variabel efikasi diri dalam memprediksi tingkat prestasi tim pdo air peserta PON XV di Surabaya adalah 95,062 persen.

2. Koef isien korelasi antara kohesivitas thm dengan prestasi tlm polo air sebesar 0 , 973 dan $p<0,05$. Ini berati terdapat korelast posistif yang sangat signifikan antara kohesivitas tim dengan prestasi tim polo air.

3. Koefisien korelasi antara efikasi dirl dengan prestasi tim polo air hasil sebesar 0,957 dan $p<0,05$. Ini berati terdapat korelasi posistif yang sangat signifikan antara efikasi diri dengan prestasl tim polo air.

4. Ada perbedaan tingkat kohesivitas tim secara meyakinkan di antara tim poio air yang bertanding pada PON $X V$ di Surabaya, yaitu tim DKI, Jawa Barat, Jawa Timur, Jambi dan tim Sumatra Utara $(F=19,117 ; \mathrm{P}<0,01)$. Jika dicermatl lebih dalam hasil penelitian ini, yaitu dengan mencoba membandingkan tingkat kohesivitas tim dengan prestasi yang diraih oleh maslng-masing tim ternyata menunjukkan ada keselarasan. Artinya makln tingginya tingkat kohesivitas tim mencerminkan nilai rerata prestasi yang tinggi pula.

5. Ada perbedaan tingkat efkasi diri secara meyakinkan di antara para pemain dalam tim polo air yang bertanding pada PON XV d Surabaya, yaitu tim DKI, Jawa Barat, Jawa Timur, Jambi dantim Sumatra Utara $(F=26,542 ; p<0,01)$. Jlka dicermati lebih dalam hasil penelitian ini, yaitu dengan mencoba membandingkan tingkat efikasi diri tim dengan prestasi yang diraih oleh masing-masing tim ternyata menunjukkan ada keselarasan. Artinya makin tinggi tingkat efikasl diri mencerminkan nilai rerata prestasl yang tinggi pula.

\section{PEMBAHASAN}

Hasil penelitian in! menunjukkan bahwa ada hubungan yang sangat signif Ikan antara kohesivitas tim dan efikasi diri secara bersama-sama terhadap prestasl tim polo air. Ini berarti bahwa seberapa tinggi tingkat kohesivitas tim, dan seberapa besar derajat efikasi diri para pemain dalam tim secara bersama-sama memberikan konstribusi sebesar 95,062 persen terhadap terciptanya prestasi tim polo air. Adanya andil kedua variabel tersebut bagi terciptanya pencapaian prestasi tim polo air sejalan dengan realitas yang berkembang dewasa in bahwa prestasi tim tidak semata-mata hanya dipengaruhi kohesivitas tim. Implikasi praktis hasil penelitlan dalam bidang manajemen menuniukkan bahwa produktivitas kerja tim dipengaruhi dan merupakan hasi kombinasi kohesivitas tim dengan norma-norma yang berlaku dalam tim (Langfred, 1998). Lebih khusus dijelaskan oleh wheelan dkk., (1998) bahwa ada hubungan yang signifikan 
antara persepsi internal dari dinamike anggota tim dengan produktivitas pacia berbagai tingkatan kelompok. Gill (1986) mergatakan bahwa kepercayaan diri pemain merupakan faktoryang menentukan dalam olahraga. Suatu konsep keyakinan diri yang berhasil dibuktikan terkalt dengen prestasi oiahraga adalah efikasi diri (Bandura, 1986). Dengan demikian adanya andil kohesivitas tim den efikasi diri secara bersama-sama terhadap prestasi tim sebagaimana terungkap dalam penelitian ini sejalan dengan hasil penelitian Higgins (1998) yang telah membuktikan bahwa secara bersama-sama kohesivitas tim, kepuasan diri dan produktivitas anggota tim umumnya berhubungan positif ketika tim mengetahui dengan jelas sasaran formal organisasi.

Sumbangan efektif variabei kohesivitas tim terhadap prestasi tim poio air adalah sebesar 71,319 persen. Hai ini sangat dimungkinkan karena cabang olahraga polo air merupakan olahraga yang tergolong interaktif, yaitu cabang olahraga yang membutuhkan interaksi, koordinasi dan kerjasama di antara pemain dalam tim (Cox, 1990). Dalam perm ai an polo air prestasi tim sangat ditentukan oieh inter aksi, koordinasi dan kerjasama di antara para pemain. Interaksi, koordinasi dan kerjasama adalah dinamis dan merupakan esensi kohesivitas tim. Steiner (dalam-Gill, 1986) mengatakan bahwa pada cabang olahraga yang membutuhkan interaksi dan koordinasi diantara sesama anggota tim, apabila proses interaksi dan koordinasi tersebut tidak berjalan maka potensi yang dimiliki tim akan hilang. Menurut Strobe dan Frey (1982), kegagaian daiam proses $|n|$ akan menyebabkan hilangnya koordinasi dan motivasi tim. HHlangnya motivasi dan koordinasi tim menyebabkan hilangnya produktivitas. Daiam kaitan ini sangatlah tepat apa yang disampaikan Yulk (1998) bahwa daiam berbagai hal kohesivitas secara tidak langsung berhubungan dengan produktivitas tim dan kohesivitas sangat berperan dalam capaian produktivitas yang tinggi. Leblh lanjut ditegaskan bahwa faktor utama yang menentukan dari berbagai pengaruh terhadap kelompok adaiah kohesivitas.

Sumbangan efektif variabel efikasi diri terhadap prestasi tim adalah sebesar 23,743 persen. Peranan efikasi diri terhadap prestasi tim telah dibuktikan dalam berbagai cabang olahraga, menurut Morris dan Summers (1995) se jumlah penelitian telah mempertimbangkan hubungan antara efikasi diri dengan prestasi olahraga kompetitif. Feltz (1982) menjelaskan bahwa efikasi diri menjadi suatu varlabel kunci dalam pencapalan olahraga dan kesehatan serta tingkah laku pada umumnya. Menu ut Baron dan Byrne (1997), bentuk efikasi difi yang tepat dapat mempertinggl baik prestasi yang berupa aktivitas fisik maupun prestasi akademik. Berbagai peneitian ini setidaknya telah mempertimbangkan dan menunjukkan bahwa pada umumnya penelitian ini menandai bahwa tingkat efikasi diri yang tinggi berkaitan dengan prestasi yang baik. Menurut Locke dkk., (1984), sebagaimana indikator pada keyakinan diri pada umumnya, efikasi dlri juga dipertimbangkan sebagai arah suatu hubungan yang dekat dengan motivasi. Efikasl diri yang tinggi akan menumbuhkan rasa percaya diri akan kemampuan dirinya daiam melaksanakan tugas. Tingginya tingkat efikasi diri para pemain akan menumbuhkan motivasi dan akan berusaha lebih keras dalam menghadapi tantangan untuk meralh prestasi yang optimal.

\section{KOHESIVITA TM DAN PRESTASI TIM POLO AIP}

Penelitian ini membuktikan bahwa terdapat hubungan yang positif antara kohesivitas tim dengan prestasi tim polo air. 
Kohesivitas tim merupakan proses dinamis yang merefleksikan kecendrungan para anggota tim untuk secara bersama-sama dalam mencapai tujuan (Carron, 1993). Cabang olahraga polo air merupakan cabang olahraga interaktif dimana unsur-unsur interaksi, koordinasi, dan kerjasama yang efektif di antara sesama pemain dalam tim akan sangat menentukan prestasi tim. Hasil penelitian komparasi antara basebal/dengan bolabasket menunjukkan bahwa tingkat prediksi antara kemampuan individu para pemain dengan prestasi tim basebal/mencapai 90 persen, sedangkan padapermainan bolabasket hanya mencapal 35 persen. Perbedaan tingkat prediksi yang mencolok ini disebabkan perbedaan tipe dan struktur kedua cabang olahraga tersebut. Keberhasilan dalam permainan baseball membutuhkan sederatan kekuatan dan keterampilan khusus para pemain, seperti pengumpan bola (pitcher), penangkap bola (catcher) dan pemukul-pemukul yang terampil, dalam permainan itu sendiri para pemain tidak melakukan interaksi yang terus menerus antara satu pemain dengan pemain lainnya. Sebaliknya dalam permainan bola basket prestasi tim sangat ditentukan oleh interaksi yang konsisten dan efektif d antara sesama pemaian dalam tim (Jones, dalam Bird dan Cripe, 1986). Berbagai hasil penelitian sebelumnya pada cabang olahraga bola basket, bola voli, sepak bola, baseball, hoki es, dan tim menembak juga menunjukkan hubungan yang positif antara Kohesivitas tim dengan prestasi (Gill, 1986).

\section{EFIKASI DIRI DAN PRESTASI TIM POLO AIR}

Hasil penelitian ini mendapatkan bahwa ada hubungan yang posit if antara efikasi diri dengan prestasi tim polo air. Efikasi diri tidak berkaitan dengan kemampuan yang sesungguhnya, tetapi merupakan persepsi subjektif atas kemampuan dirinya untuk melakukan tugas khusus. Bandura (1986) mendefinisikan bahwa efikasi diri sebagai suatu keyakinan seseorang bahwa dirinya memiliki kemampuan untuk melakukan tugas khusus. Para pemain yang yang memiliki efikasi diri tinggi mereka dapa mengendalikan situasi yang mengganggu sehingga menimbulkan perasaan mampu menge ndalikan kejadian atau masalah secara efektif. Upaya keras yang dilakukan oleh pemain dalam melakukan aktivitas olahraga menunjukkan efikasi diri yang lebih besaryang akan menyebabkan usaha yang lebih besar pula. Locke dan Frederick (1984) mengatakan bahwa efikasi diri yang tinggi akan menumbuhkan rasa percaya diri atas kemampuan dirinya dalam melaksanakan keberhasilan tuggas. Baron dan Byme (1997) menyimpulkan bahwa efikasi diri yang tepat dapat mempertinggi prestasi baik yang terkait dengan aktivitas fisik maupun prestasi akademik. Feltz (1982) dengan berdasar pada teori belajar milik Bandura telah menguji hubungan antara efikasi ciri da gejolak fisiologis dengan pencapaian prestasi penyelam. Hasilnya menunjukkan bahwa efikasi ciri merupakan prediktor yang paling kuat bagi prestasi penyelam. Begitu pula peneltian eksperimen menunjukkan bahwa subjek yang memiliki efikasi diri tinggi mereka memperoleh skor rata-rata 80 persen terhadap kewaspadaan tugas, sedangkan subjek dalam kondisi efikasi diri rendah hanya medapat skor rata-rata 20 persen terhadap prestasi kewaspadaan tugas (Sanna, 1992). Argumentasi teoritis dan hasil penelitian sebagaimana tersebut di atas mendukung atau sejalan dengan hasil penelitian ini bahwa ada hubungan yang positif antara efikasi diri dengan prestasi tim polo air. 


\section{PEREEDAAN TINGKAT KOHESIVITAS TH POLO AIR}

Penelitian ini menunjukkan ada perbedaan yang signifikan tingkat kohesivitas tim of antara masing-masing tim polo air yang bertanding pada PON XV Surabaya. Ada empat komponen yang memberikan kontribusi terhadap kohesivitas tim dalam olahraga, yaitu faktor lingkungan, faktor prlbadi, faktor kepemimpinan, dan faktor kondisi tim (Carron dalam Gill, 1986). Kondisi keempał faktor tersebut tidak mungkin dirasakan sama oleh setiap tim yang bertanding pada PON XV di Surabaya, karena mereka berasal dari lingkungan sosial berbeda, serta faktor keadaan tim yang heterogen dengan segudang permasalahan yang berbeda pula. Hasilwawancara dengan pelatih dan officialtim dan pengamatan langsung pada saat mereka bertanding setidaknya dapat mengungkap perbedaan tersebut. Tim poio air Jawa Timur, DKI Jakarta dan Sumatra Utara memperoleh dukungan sosial dan finansial yang begitu besar. Ketiga tim tersebut dalam rangka persiapan menuju PON XV melakukan latih tanding ke luar Negeri yaitu Singapura dan Malaysia serta dijanjikan bonus puluhan juta rupiah jika berhasil memperoleh medali emas. Dukungan sosial dan finansial sebaik itu tidak diterima oleh tim Jawa Barat dan Jambi. Bahkan untuk tim Jambi mereka kesulitan untuk mendatangkan pelatih profesional, sehingga dalam pertandingan pelath harus mnerangkap sebagai pemaian. Bagaimanapun perbedaan tersebut akan melahirkan orientasl tim, harapan, perasaan untuk sukses, stabilitas tim, akan berbeda pada masing-masing tim. Para pemain Jatim dan DKI Jakarta yang dijanijikan bonus jutaan rupiah bila berhasil meraih medali emas jelas akan memiliki orientasi, perasaan untuk sukses dan motivasi yang lebih kuat dibandingkan para pemain tim lainnya. Dalam Kondisi ini para pemain DKI dan
Jatim akan memiliki komitmen dan menunjukkan perilaku disiplin dalam melakukan aktivitas yan terkait dengan kepentingan tim seperti menjalani latihan, kehadiran latihan, semangat berlatih, dan semangat bertanding yang pada gilirannya akan bermuara pada kohesivitas tim yang tinggi. Hai ini ditegaskan oleh Jhonson dan Jhonson (199t) bahwa tingkat kohesivitas tim dicirlkan oleh beberapa hal di antaranya kehadiran anggota tim, anggota datang tepat waktu, kepercayaan dan dukungan diantara sesama anggota tim, dan individu-individu diterima dalam kelompok. Pendapat ini sejalan denagn hasil perielitian yang menunjukkan bahwa tingkat kohesivitas tim yang tinggi dindikasikan adanya usaha keras untuk mencapai tujuan optimal tim (Cawight, 1968; Warson \& Jhonson, 1972, dalam Jhonson danJhonson, 1991) .

\section{PERBEDAAN TINGKAT EFIKASI DIRI TIM POLO AIR}

Hasil penelittan ini juga menunjukkan adanya perbedaan tingkat efikasi diri diantara masing-masing tim polo air peserta PON XV di Surabaya. Tim polo air Jawa Timur memiliki tingkat efikasi diri rata-rata yang paling tinggi dibandingkan tim-tim lainnya seperti DKI Jakarta, Sumatra Utara, Jawa Barat dan tim Jambi. Tim polo air yang memiliki efikasi diri rata-rata tinggi cenderung akan bekerja leblh keras untuk meraih prestasi terbaik. Locke dkk., (1984) mengatakan bahwa efikasi diri menumbuhkan rasa percaya diri akan kemampuan dirinya dakam melaksanakan keberhasilan tugas. Meskipun tidak menunjukkan perbedaan yang signifikan hasll penelitian ini membuktikan bahwa skor prestasi rata-rata tim polo air Jawa Timur lebih baik dari tim polo air DKI Jakarta yang not a bene adalah juara pertama cabang polo air PON XV di Surabaya. 
Prestasi orang mengenal efikasi dirinya untuk suatu tugas merupakan hasil dari suatu proses kognitif yang melibatkan pengalaman masa lalu dan keterkaitannya dengan masa sekarang. Proses kognitif ini merupakan kajian yang lebih luas, yang oleh Bandura (1986) digambarkan sebagai teori kognitif sosial. Terjadinya perbedaan tingkat efikasi diri pada masing-masing tim tidak terlepas dari perbedaan kognitif, seperti pengalaman masa lalu tim, latar belakang tim, faktor individual pemain, harapan tim dan kondisi pada saat bertanding. Tim Jawa Timur sebagai tuan rumah PON XV, pada saat bertanding selalu mendapat dukungan penonton yang begitu besar dan sangat fanatlk. Secara teoritis kondlsi $|n|$ akan meningkatkan efikasi diri dan motivasl untuk menang. Berdasar analisis yang ekstensif terhadap 241 hasil penelitlan disimpulkan bahwa kehadiran orang lain tidak meningkatkan kualitas prestasl tim balk untuk tugas sederhana maupun tugas kompleks. Namun demikian dapat meningkatkan prestasi rata-rata untuk tugas sederahana (Bond dan Travis dalam Wheelan, 1994). Berdasarkan argumentas| teoritls dan hasll penelitlan tersebut menunjukkan dan sekaligus memperkuat hasil penelitian ini bahwa terdapat perbedaan yang signifikan tingkat efikasi diri diantara tim polo air yang bertanding pada PON $X V$ d Surabaya.

\section{SIMPULAN}

Dari hasil-hasil kajjan yang dikemukakan dapat ditarlk simpulan di antaranya adalah sebagai berikut:

1. Kohesivitas tim dan efikasi diri secara bersama-sama memberikan kontribusi yang sang at signifikan terhadap prestasi thr polo air peserta PON XV tahun 2000 di Surabaya. Sumbangan efektif kedua variabel tersebut ter hadap prestasi tim polo air adalah sebesar 95,062 persen.
2. Terdapat hubungan yang positif dan sangat signifikan antara kohesivitas tim dengan prestasi tim polo air. Tim polo air yang memilikitingkat kohesivitas tim thnggi juga memperoleh prestasi yang tinggi.

3. Terdapat hubungan yang positif dan sangat signifikan antara efikasi diri dengan prestasi tim polo air. Tim polo air yang para pemainnya memlliki tingkat eflkasi diri rata-rata tlnggijuga memperoleh prestasi yang tinggl.

4. Terdapat perbedaan yang signifikan tingkat kohesivitas tim diantara masingmasing tim yang bertanding pada PON $X V$ di Surabaya. Tim dengan tingkat kohesivitas tim yang tinggi memilikl prestasi yang tlnggl pula.

5. Terdapat perbedaan yang signifikan tingkat efikasi dirl diantara masingmasing tim yang bertanding pada PON XV di Surabaya. Tim dengan yang thngkat efikasl diri para pemainnya tinggl memiliki prestasl yang tinggi puia.

\section{DAFTAR PUSTAKA}

Anshel, M.H., 1990, Psychology Spat From Theory o Practice. Scottsdale Arizona: Gorsuch Scarisbbrick Publishers.

Bandura, A., 1986, Soclal Foundatlons of Thought an Action. NJ: Englewood Clifts Printice Hall.

Bandura, A., 1977, Self-efficacy: Toward a Unifying theory of behavoir change, Psychological Revlew, 84, 191-215.

Bird, A.M., \& Cripe, B.K., 1986, Psychology and Sport Behavior. ST. Louis: Times Mirror/Mosby College Publishing.

Carron, A.V.,(1993). The Sport Tim as an Elfective Group(dalam William: Applied Sport Psychology Personal Growth to Peak Performance). London: 
Mayfield Publishing Company.

Cox, H.R, 1990, SportPsychology Con cepts and Applications, Dubuque: Wm.C Brow Publishers.

Davies, D., 1989, Psychological Factors in Competitive Sport, Philadhelphia: The Falmer Press Taylor \& Francis inc.

Feltz, D.L., 1982, Paht analysis of the causal elements of Bandura's theory of self efficacy and an anxiety based model of avoidance behavior, Joumal of Porsonalily and Social Psychology. 42, 764-781.

Gill, D.L., 1986, Psychological Dinamics of Sport, Illinois: Human Kinetic Publisher, Inc.

Gully, S.M., Devine, D.J., \& Whitney, D.J., 1995, A meta analysis of cohesion and performance: Effect of level analysis and task interdependence. Small Group Reseach, 26, 497-520.

Higglsn, J.M., 1982. Human Relations Consepts and Skill. New York: Random House, Inc.

Jhonson D.W, and Jhonson F.D, 1991. Joining Together Group Theory and Group Skil!! New Jersey: Prentice-Hill International, Inc.

Langfred, C.W., 1998. \& Group CohesivenessA Double-Edged Sword? Anggota Investigation of Effect of Cohesivenesson Ferformance. Small. Group Researsh, 29, 124-143.

Locke, E.A., E.Frederick, C. Lee, \& P. Bobko, 1984. Effect of Self Efficacy, Goal, and Task Strategles on Task Performance. Journal of Applied Psychology, 36, 214-25t.
Loy, J.W., McPherson, B.D., \& Kenyon, G. 1978, Sport and Social System A Guide to the Analysis Problems and Literature, London: Addison-Wesley Fublishing Company.

Morris, T., \& Summer.J. 1995, Sport Psychology Theory, Applications and Issues. Brisbane: John Willey \& Sons.

Nossek, J., 1982, General Theory of Trainnin. Lagos National Institute for Sport: Pan African Press Lid. .

Pate, R.R., McCleanaghan, B., \& Rotella, R., 1993, Scientific Foundations of Coaching (terjemahan Kasiyo Dwijowinoto), Semarang: IKIP Semarang Press.

Sanna, L.J., 1992. Self-efficacy Theory: Implications for Social Facilitation and Social Loafing. Journal of Personallty and Social. Psychology, 62, 774-786.

Setyobroto, S., 1993, Psikologi Kepelatihan, Jakarta: CV Jaya Sakti.

Shaw, M.E.., 1979, Dynamics of Small Group Behavior. New Delhi: Tata McGraw-Hill PUblishing Company Ltd.

Singgih, D.G., 1989, Psikologi Olahraga. Jakarta: PT BPK Gunung Mulya.

_-, 2000, Sumbangan Psikologi bagi Dunia Olahraga (dalam Supratiknya dkk:- Tantangan Fsikologi Menghadapi Milenium Baru). Yogyakarta: Yayasan Pembina Fakultas Psikologi UGM.

Siregar, M.F., 1978, Peranan Olahraga dalam Pembangunan Bangsa (dalam Prisma No. 4 Mel, 1978), Jakarta: LP3S. 
Straub, W.F., 1980, Sport Psychology An Analysis of Athelete Behavior. New York: Movement Publishing Company.

Strobe, W., \& Frey, B.S,. 1982. Self-interest and Collective action: the economics and psychology of public good British Journal of Social Psychology, 21, 121-137.

Weiss, M.R., Weise, D.M., \& Klint, K.A, 1989, Head over heels with succses: The relationship between self efficacy an performance in competitive youth gymnastics. Journal of Sport and Exercise Psychology, 11, 444-451.
Werner, G. 1996. Constitution and Rule Swimming, Open W ater Swimming, Diving, Water Polo, Synchronized Swimming, Master Facilities and Medical. Switzerland: FINA.

Williams, J.M., 1993, Applied Sport Psychology Person Growth to Peak Performance. London: Mayfield Publishing Company.

Yulk, G. 1998. Leadership in Organization. Englewoode Cliffs, New Jersey: Prentice-Hall Intemational, Inc. 